\section{Women on the Board: Do They Manage Earnings? Empirical Evidence from European Listed Firms}

\author{
Tiago Gonçalves ${ }^{1}$ \\ Cristina Gaio' \\ Tatiana Santos 1 \\ ${ }^{1}$ Universidade de Lisboa, ISEG - Lisbon School of Economics \\ \& Management, Lisboa, Portugal
}

Received on

05/10/2018

Approved on

$10 / 23 / 2018$

Responsible editor:

Prof. Dr. Leire San-Rose

Evaluation process:

Double Blind Review

\begin{abstract}
Purpose - To analyse the impact of women on boards of directors and the gender of CEOs and CFOs on the earnings management and, thus, on the quality of the financial information of European listed firms.
\end{abstract}

Design/methodology/approach - Archival research based on data collected from Bloomberg, complemented by information hand collected from financial reports, for a sample of European listed firms, covering 2007-2013.

Findings - The main results show that only CFO gender has an impact on both the intensity and direction of earnings management. Firms with a woman $\mathrm{CFO}$ presented less earnings management than those with a male CFO. We also find evidence that women manage earnings downwards, such that discretionary accruals are used to decrease reported earnings.

Originality/value - We contribute to the still scarce literature on the impact of gender on earnings management and financial reporting quality, namely by providing international evidence, since the extant literature focuses on the USA.

Keywords - Earnings Management, Gender, Listed Firms, Corporate Governance

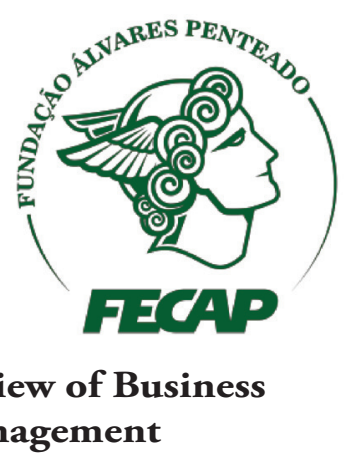

DOI: $10.7819 /$ rbgn.v21i3.4010 


\section{Introduction}

Earnings management practices can affect the quality of financial reporting and the decision-making of different users of accounting information. Earnings management occurs when managers use judgment in financial statements and in structuring transactions in order to alter financial reports (Healy \& Wahlen, 1999). The growing focus of the literature on the issue of earnings management thus comes as no surprise (Peni \& Vähämaa, 2010).

The issue of gender diversity and its implications for company management is also the focus of growing interest from different areas of research. There is evidence that there are significant behavioural differences between genders (Bernardi \& Arnold, 1997; Byrnes et al., 1999; Francis et al., 2015; Heminway, 2007) that can affect financial reporting practices. The growing interest in studying gender diversity is the result of pressures from a number of entities, such as national regulators, the European Commission and the media, to increase the participation of women in prominent positions (Terjesen et al. al., 2009; European Commission, 2012). Specifically, the imposition of quotas for women on the boards of directors of publicly-traded and state-owned companies is already a reality in many countries. However, the presence of women in top positions remains modest. Globally, only $10 \%$ of board members are female (Terjesen et al., 2015).

The literature that analyses the influence of gender on the quality of financial reporting, and particularly on earnings management, is still scarce and inconclusive, focusing mostly on the North American reality. Gavious et al. (2012), among others, found evidence that earnings management is lower when CEOs and CFOs are female. In turn, Arun et al. (2015) concluded that a female presence on the board is associated with downward earnings management, suggesting that women are more likely to engage in more conservative financial reporting policies. However, no correlation was found in other studies between the presence of women and the level of earnings management (Ye et al., 2010; Ge et al., 2011; Arun et al., 2015). According to Adams et al. (2015), more research is needed on the effects of gender diversity, particularly at the board level, along with more international studies focusing on different countries and not just on the reality of a single country. Birnberg (2011) also argues that the accounting literature should pay more attention to the gender issue, given that there is little research on this subject and the contradictory results found.

This research aims at analysing the association between the presence of women on boards and earnings management at the European level. That is, the aim is to analyse to what extent the presence of women on boards of directors, and when they perform the role of CEO or $\mathrm{CFO}$, affects the earnings management and, consequently, the quality of the reported financial information of European listed companies.

To measure earnings management we chose two types that are widely used in the literature: the absolute value of discretionary accruals, ascertained using the modified Jones model (Dechow et al., 1995); and accruals size, as a proxy to ascertain when managers use discretion in earnings statements (Leuz et al., 2003). To measure the presence of women in business management three measures normally found in the literature were used: the percentage of women on the board of directors and the gender distribution in CEO and in CFO positions. The sample of this research is made up of 373 listed companies from 17 European countries and covers the period from 2007 to 2013.

The main results of the study suggest that only the gender of the CFO has an impact on the size and direction of earnings management. There is evidence that companies with female CFOs engage less in earnings management than companies with male CFOs. There is also evidence that women perform downward earnings management; that is, they use discretionary accruals to manage earnings downwards, which 
suggests that women behave more conservatively than men in terms of financial reporting. These results are in line with those obtained in previous studies (Peni \& Vähämaa, 2010; Vähämaa, 2014).

The aim of this study is to contribute to the still scarce literature on the impact of gender diversity as regards earnings management and the quality of financial reporting, adopting an international approach, as most studies focus only on one country, particularly the USA. The results of this study are of interest to different stakeholders in the financial reporting process, namely analysts, investors, creditors and regulators.

The study is divided into 5 sections. In the next section a brief review of the literature is carried out. Section 3 describes the sample and the methodology used. Section 4 shows the analysis of the results. Finally, section 5 presents the main conclusions, limitations and suggestions for future research.

\section{Literature review}

\section{I Earnings management}

Earnings management practices probably raise one of the most important ethical issues faced by accountants (Merchant \& Rockness, 1994). Companies that engage in them may mislead stakeholders about the true profitability and stability of their operations, which can undermine the decision-making process and the efficient workings of the capital markets. In fact, the information disclosed by companies is used to set the prices of securities and investors use these to decide whether to buy, sell or hold securities. It may not be possible for the markets to evaluate securities correctly when the information does not correctly reveal the financial position and performance of the companies. Because earnings management can hide actual performance and decrease the ability of users to make informed decisions, it can be seen as an agency cost (Xie et al., 2003).

Earnings management is the practice of choosing accounting estimates or changing the timing of some operational decisions in order to move results and to achieve the desired goal (Merchant \& Rockness, 1994). It is a deliberate interference in financial statements in order to gain a certain advantage for management, the company or both (Schipper, 1989; Healy \& Wahlen, 1999). Earnings management occurs when managers use judgment in financial statements and in structuring operations in order to alter financial statements to "fool" some stakeholders about the economic performance of the company, or influence contractual results that depend on reported accounting results (Healy \& Wahlen, 1999).

According to Beneish (2001), there are two perspectives on earnings management: the opportunistic perspective and the information perspective. The opportunistic perspective is marked by the fact that managers try to "fool" investors, acting on their own behalf and to the detriment of shareholders' interests (Healy \& Wahlen, 1999; Schipper, 1989). In turn, from the information perspective, managers manage earnings in order to reduce information asymmetry, disclosing private information to investors, in particular, about their expectations regarding the company's future cash flows (Peasnell et al., 2005; Dechow \& Schrand, 2004; Subramanyam, 1996). In the literature the opportunistic perspective prevails.

According to Healy \& Wahlen (1999), aspects related to the capital markets and contractual and legal issues may lead to earnings management practices. With regard to the capital markets, managers can use earnings management practices to report earnings that meet analysts' and investors' expectations or to influence share prices on the stock market. With regard to contractual issues, the desire to obtain low-cost external financing and avoid breaches of contract clauses also leads to earnings management. Finally, regulatory issues may motivate earnings management, either for tax reasons in order to reduce the amount of taxes payable, or to avoid 
specific regulations in force in a particular activity sector.

Accruals, which represent the share of earnings that are not reflected in cash flows, create an opportunity for earnings management as they require managers to make forecasts, estimates and judgments. The greater the degree of discretion, the greater the propensity to manage earnings, given that they provide greater flexibility when it comes to ascertaining and measuring impacts. Examples of their timing and prevalence can be found consistently in the literature. Bressan et al. (2017) show the use of accruals estimates by credit unions affiliated with the UNICRED system as a means to smooth earnings and, consequently, reduce the variability of returns, presenting an image of solidity to members. Linhares et al. (2018) found evidence of the positive association between earnings management and deviations from ideal levels of investment in companies listed on the BM\&FBOVESPA. This prevalence of opportunistic earnings management is not mitigated even when the regulator obliges audit firms to rotate in order to improve scrutiny and promote a lower level of earnings management (Da Silva \& Bezerra, 2010).

\subsection{Gender diversity}

The literature in the areas of psychology, sociology and management recognizes that there are significant differences between genders, particularly when it comes to leadership styles, communication, risk aversion and level of conservatism when making decisions (Bernardi \& Arnold, 1997; Byrnes et al., 1999; Francis et al., 2015; Heminway, 2007). These differences and their implications for business management have led to a growing interest of the literature in the issues of gender diversity.

Bruns \& Merchant (1990) showed that earnings management is generally viewed as an ethical issue by managers and accountants. The differences between men and women as regards business ethics have been widely studied in the literature in this field and there is evidence of differences between women and men when it comes to values and interests and the propensity to engage in unethical business behaviours (Gilligan, 1982; Betz et al., 1989). Women are more ethical in the workplace, even when they could personally benefit from unethical behaviour, and are less likely to engage in unethical behaviour with a view to obtaining financial gains (Betz et al., 1989; Bernardi \& Arnold, 1997; Khazanchi, 1995). Men are interested in having a successful career and gaining economic benefits and are more likely to break the rules in order to achieve competitive success. On the other hand, women have a greater tendency to help others, to have harmonious relationships and are less likely to engage in unethical behaviour (Betz et al., 1989; Butz \& Lewis, 1996; Mason \& Mudrack, 1996).

Furthermore, women tend to be more risk-averse in general (Byrnes et al., 1999) and, in particular, more risk-averse when it comes to investment (Cohn et al., 1975; Riley \& Chow, 1992) and financing decisions (Jianakoplos \& Bernasek, 1998)47 per cent compared with graduated compression stockings, and 48 per cent compared with mini-dose heparin. IPC devices significantly decreased the relative risk of DVT compared with placebo in high-risk patients such as neurosurgery and major orthopedic surgery patients and in modest risk patients such as general surgery patients. In major orthopedic surgery patients, the incidence of DVT was similar for IPC- and warfarin-treated patients; however, IPC was significantly better than warfarin at decreasing the incidence of calf only DVT, whereas warfarin seemed to be better at decreasing proximal DVT. IPC devices are effective in decreasing the incidence of DVT in patients at moderate to high risk and are probably more efficacious than graduated compression stockings or mini-dose heparin; however, IPC devices are not protective against pulmonary embolism. The data directly comparing the various methods of compression (knee-high versus thigh-high sleeves and gradedsequential versus uniform compression. They 
also tend to make more conservative and prudent decisions as regards financial statements (Francis et al., 2015). Heminway (2007) argues that women are more trustworthy than men and thus less likely to manipulate financial statements and other disclosures. Srinidhi et al. (2011) also argue that women are more cautious in financial decision-making, abide more by the rules, and perform better supervision of financial statements.

\subsection{Relationship between earnings management and gender}

In order to restructure the boards of directors in European countries, regulators have proposed making the presence of women in management a legal requirement. According to Habib \& Hossain (2013), the logic inherent in these reforms relates to the fact that gender diversity improves managers' oversight over corporate activities.

The literature that examines the impact of gender diversity on earnings management is still scarce and inconclusive, and mostly studies the North American reality. There are studies that point to the fact that a female presence in prominent positions (Krishnan \& Parsons, 2008), on the board of directors (Srinidhi et al, 2011) and in CFO positions (Barua et al., 2010; Peni and Vähämaa, 2010; Gavious et al., 2012; Vähämaa, 2014) positively affects earnings quality.

However, Srinidhi et al. (2011)there is little supporting empirical evidence. We fill this void by examining the relation between female board participation and the quality of reported earnings. Using a sample of U.S. listed firms from 2001 to 2007, we show a positive relation between the presence of female directors (female nonexecutive directors, female audit committee members, who studied the association between the participation of women on boards of directors and the earnings quality in US companies, found that companies with greater female participation in their boards of directors post higher quality results, but warn that there are studies that do not find evidence of a positive effect of a female presence on earnings management and earnings quality, specifically in terms of CFO and/or CEO positions (Ye et al., 2010; Ge et al., 2011; Arun et al., 2015).

Ye et al. (2010) tried to prove if the gender effect on earnings quality in developing countries is the same as that found in the literature on developed countries. Thus, they researched possible associations between the top executives' gender and earnings quality in China, the largest emerging market. Contrary to what has been documented in developed markets, such as the US, their findings showed that earnings quality is not significantly different between companies with male executives and female executives.

Arun et al. (2015) analysed the relationship between earnings management practices and women directors in UK companies. They concluded that companies with a greater number of women directors and independent directors are more likely to engage in more conservative financial reporting policies and generally use downward earnings management practices. However, they saw that the gender of the CFO does not statistically and significantly affect earnings management practices. Lakhal et al. (2015) found similar results in French listed companies. Although they found that the presence of women on the board reduces earnings management, they found no evidence to support the idea that the CEO's and CFO's gender affects earnings management practices.

This study thus intends to answer the following research questions in the context of European listed companies:

Q1: Are earnings management practices lower in companies with women on their boards of directors?

Q2: Are earnings management practices lower in companies with female CEOs?

Q3: Are earnings management practices lower in companies with female CFOs? 


\section{Data and methodology}

\section{I Sample and data collection}

The data used in the study were taken from the Bloomberg database, except the information about the gender of the chief executive and chief financial officers, which was collected manually from the Annual Reports. The initial sample is composed of listed companies based in Europe and covers 2007 to 2013.

Companies in the financial sector were excluded from the initial sample given their specific characteristics, which could lead to biases in the results, along with companies for which information was not available for all the variables. Sectors with fewer than 6 firms and countries with fewer than 5 firms were also not considered. The sectors were classified according to the Industry Classification Benchmark (ICB).

The final sample is made up of 373 companies, from 17 European countries and 16 activity sectors, and covers the 7 -year period between 2007 and 2013. Table 1 shows the breakdown of the sample by country. The most representative country in the sample is the United Kingdom (33.78\%), followed by France (11.26\%) and Germany (8.04\%).
Table 1

\section{Breakdown of the sample by country}

\begin{tabular}{lcc}
\hline Country & No of Companies & Percentage \\
\hline Germany & 30 & 8,04 \\
Austria & 6 & 1,61 \\
Belgium & 7 & 1,88 \\
Denmark & 16 & 4,29 \\
Spain & 12 & 3,22 \\
Finland & 20 & 5,36 \\
France & 42 & 11,26 \\
Greece & 5 & 1,34 \\
The Netherlands & 11 & 2,95 \\
Ireland & 5 & 1,34 \\
Italy & 18 & 4,83 \\
Norway & 12 & 3,22 \\
Portugal & 7 & 1,88 \\
United Kingdom & 126 & 33,78 \\
Sweden & 25 & 6,70 \\
Switzerland & 26 & 6,97 \\
Turkey & 5 & 1,34 \\
\hline Total & $\mathbf{3 7 3}$ & $\mathbf{1 0 0}$ \\
\hline
\end{tabular}

\subsection{Methodology}

\subsection{Earnings management measures}

Two widely used measures in the literature were considered as a means to measure earnings management: discretionary accruals, calculated according to the Modified Jones Model developed by Dechow et al. (1995); and the magnitude of accruals (Leuz et al., 2003). Accruals create an opportunity for earnings management because they require managers to forecast, estimate and make judgements. The greater the degree of discretion, the greater the tendency to manage earnings (Dechow \& Schrand, 2004).

The first step in calculating the first measure, EMJones, was to obtain the total accruals using the traditional balance sheet approach (Dechow et al., 1995):

$$
\begin{aligned}
& \mathrm{TA}_{\mathrm{i}, \mathrm{t}}=\Delta \mathrm{CA}_{\mathrm{i}, \mathrm{t}}-\Delta \mathrm{Cash}_{\mathrm{i}, \mathrm{t}}-\Delta \mathrm{CL}_{\mathrm{i}, \mathrm{t}}+ \\
& \Delta \mathrm{SD}_{\mathrm{i}, \mathrm{t}}-\mathrm{DepAm}_{\mathrm{i}, \mathrm{t}}
\end{aligned}
$$


where $\mathrm{TA}_{\mathrm{i}, \mathrm{t}}$ is the total of accruals of company $\mathrm{i}$ in year $\mathrm{t} ; \triangle \mathrm{CA}$ is the annual change in current assets; $\Delta$ Cash is the annual variation in cash and cash equivalents; $\triangle \mathrm{CL}$ is the annual change in current liabilities; $\triangle S T D$ is the annual change in short-term debt; and DepAm is the value of depreciation and amortization in year $\mathrm{t}$.

We then estimated the $\alpha_{i}$ coefficients for each activity sector and year:

$\mathrm{TA}_{\mathrm{i}, \mathrm{t}}=\alpha_{1}+\alpha_{2} \Delta \mathrm{SAL}_{\mathrm{i}, \mathrm{t}}+\alpha_{3} \mathrm{FTA}_{\mathrm{i}, \mathrm{t}}+\varepsilon_{\mathrm{i}, \mathrm{t}}$

where $\triangle \mathrm{SAL}$ is the annual change in sales and FTA is the tangible fixed assets in year $t$, deflated by total assets of the previous year.

Based on the estimates of the $\alpha_{i}$ coefficients, non-discretionary accruals for each company and year $\left(\mathrm{NDA}_{\mathrm{i}, \mathrm{t}}\right)$ were calculated in order to obtain the first measure of earnings management:

EMJones $_{\mathrm{i}, \mathrm{t}}=\mathrm{TA}_{\mathrm{i}, \mathrm{t}}-\mathrm{NDA}_{\mathrm{i}, \mathrm{t}}$

Finally, in the base model described below, we decided to analyse the absolute value of this measure, with the purpose of studying the intensity of the level of discretionary accruals.

Based on Leuz et al. (2003), the second measure of earnings management was calculated as follows:
EMLeuz $_{\mathrm{i}, \mathrm{t}}=\mid$ Accruals $_{\mathrm{i}, \mathrm{t}}|/| \mathrm{OCF}_{\mathrm{i}, \mathrm{t}} \mid$

in which OCF is the operating cash flow, which results from subtracting the accruals from the operating result, and the Accruals are obtained through:

Accruals $_{\mathrm{i}, \mathrm{t}}=\left(\Delta \mathrm{CA}_{\mathrm{i}, \mathrm{t}}-\Delta \mathrm{Cash}_{\mathrm{i}, \mathrm{t}}\right)-$
$\left(\Delta \mathrm{CL}_{\mathrm{i}, \mathrm{t}}-\Delta \mathrm{STD}_{\mathrm{i}, \mathrm{t}}-\Delta \mathrm{I}_{\mathrm{i}, \mathrm{t}}\right)-\operatorname{DepAm}_{\mathrm{i}, \mathrm{t}}$

where $\Delta \mathrm{I}$ is the annual change in income taxes payable.

\subsubsection{Gender variables}

In order to study the influence of women on earnings management, three gender variables were created based on previous studies: women, corresponding to the percentage of women on the board of directors; CEO, a dummy variable that assumes the value " 1 " if the CEO is female, and " 0 " otherwise; and CFO, a dummy variable that assumes the value " 1 " if the CFO is female, and " 0 " otherwise (Arun et al., 2015; Barua et al., 2010; Peni \& Vähämaa, 2010; Ye et al., 2010).

\subsubsection{Empirical model}

To test the hypotheses under study, the following empirical models were developed:

$\mid$ EMJones $_{i, \mathrm{t}}=\alpha+\beta_{1}$ WOMEN $_{\mathrm{i}, \mathrm{t}}+\beta_{2} \mathrm{CEO}_{\mathrm{i}, \mathrm{t}}+\beta_{3} \mathrm{CFO}_{\mathrm{i}, \mathrm{t}}+\beta_{4} \mathrm{SGROWTH}_{\mathrm{i}, \mathrm{t}}+\beta_{5} \mathrm{SIZE}_{\mathrm{i}, \mathrm{t}}+\beta_{6} \mathrm{IND}_{\mathrm{i}, \mathrm{t}}+$ $\beta_{7}$ OCF $_{\mathrm{i}, \mathrm{t}}+\beta_{8} \mathrm{MB}_{\mathrm{i}, \mathrm{t}}+\beta_{9}$ LOSS $_{\mathrm{i}, \mathrm{t}}+\beta_{10}$ ROA $_{\mathrm{i}, \mathrm{t}}+\beta_{11}$ YEAR $_{\mathrm{i}}+\beta_{12}$ COUNTRY $_{\mathrm{i}}+\beta_{13}$ SECTOR $_{\mathrm{i}}+\varepsilon_{\mathrm{i}, \mathrm{t}}$

EMLeuz $_{i, t}=\alpha+\beta_{1}$ WOMEN $_{i, t}+\beta_{2}$ CEO $_{i, t}+\beta_{3}$ CFO $_{i, t}+\beta_{4}$ SGROWTH $_{i, t}+\beta_{5}$ SIZE $_{i, t}+\beta_{6}$ IND $_{i, t}+$ $\beta_{7}$ OCF $_{\mathrm{i}, \mathrm{t}}+\beta_{8} \mathrm{MB}_{\mathrm{i}, \mathrm{t}}+\beta_{9}$ LOSS $_{\mathrm{i}, \mathrm{t}}+\beta_{10}$ ROA $_{\mathrm{i}, \mathrm{t}}+\beta_{11}$ YEAR $_{\mathrm{i}}+\beta_{12}$ COUNTRY $_{\mathrm{i}}+\beta_{13}$ SECTOR $_{\mathrm{i}}+\varepsilon_{\mathrm{i}, \mathrm{t}}(7)$

where: SGROWTH is the annual sales growth; SIZE is the size of the company; IND is the level of indebtedness; OCF is the operating cash flow; $\mathrm{MB}$ is the market-to-book ratio; LOSS indicates whether or not the company generated a loss; and ROA is the return on assets. The $\mathrm{i}$ index represents each of the companies in the sample $(i=1,2, \ldots$, $373)$ and the $t$ index refers to the year $(t=2007$, 2008, ..., 2013).
Given that earnings management may differ over time and between sectors, control variables were also included for potential temporal and activity sector effects (Arun et al., 2015; Peni \& Vähämaa, 2010). The YEAR variable is a dummy variable referring to the year and SECTOR is a dummy variable referring to the sector according to the ICB. A dummy variable called COUNTRY was also used to control the 
possible effects of country characteristics on earnings management. For more detail about the variables under study, see the information contained in the Appendix. The estimation method used was pooled OLS. The standard errors were grouped by company and year, in order to correct the presence of autocorrelation.

\section{Analysis of the results}

\section{I Descriptive statistics}

Table 2 presents the descriptive statistics of the variables under study. From analysing this table, we see that the mean of the EMJones variable is -0.0082 , thus we can state that, on average, the companies in the sample engage in downward earnings management, that is, they reduce their earnings. Arun et al. (2015) have also highlighted that UK companies tend to be conservative and prefer to engage in downward earnings management practices. As regards the mean EMLeuz, we see that it is in accordance with that of the study by Leuz et al. (2003).

Table 2

\section{Descriptive statistics}

\begin{tabular}{|c|c|c|c|c|c|c|}
\hline Variable & Observations & Mean & Median & Standard Deviation & Minimum & Maximum \\
\hline EMJones & 2.611 & $-0,0082$ & $-0,0079$ & 0,0642 & $-0,4493$ & 0,5384 \\
\hline EMJones & 2.611 & 0,0433 & 0,0298 & 0,0481 & 0 & 0,5384 \\
\hline EMLeuz & 2.611 & 0,5016 & 0,3663 & 0,5897 & 0,0003 & 5,9306 \\
\hline WOMEN & 2.611 & 13,1382 & 11,1110 & 12,2170 & 0 & 70 \\
\hline $\mathrm{CEO}$ & 2.611 & 0,0253 & 0 & 0,1570 & 0 & 1 \\
\hline $\mathrm{CFO}$ & 2.611 & 0,0582 & 0 & 0,2342 & 0 & 1 \\
\hline SGROWTH & 2.611 & 0,0511 & 0,0440 & 0,1840 & $-0,7611$ & 1,8506 \\
\hline SIZE & 2.611 & 8,2722 & 8,2408 & 1,6371 & 3,8748 & 12,6895 \\
\hline IND & 2.611 & 0,5898 & 0,6057 & 0,1590 & 0,0874 & 0,9913 \\
\hline OCF & 2.611 & 0,1003 & 0,0896 & 0,0673 & $-0,4162$ & 0,4169 \\
\hline $\mathrm{MB}$ & 2.611 & 2,5168 & 1,9170 & 2,0239 & 0,0701 & 19,4603 \\
\hline LOSS & 2.611 & 0,0999 & 0 & 0,2999 & 0 & 1 \\
\hline ROA & 2.611 & 0,0571 & 0,0502 & 0,0711 & $-0,5749$ & 0,5610 \\
\hline
\end{tabular}

With regard to the three manager gender independent variables, we see that the sample companies have, on average, $13.14 \%$ women on their boards of directors. There is a large discrepancy between the minimum value $(0 \%)$ and the maximum value $(70 \%)$ of this variable. The maximum value of $70 \%$ is for one company only in one year alone and only 13 companies out of 373 (37 observations) have 50\% women on their boards or more. However, the minimum value of $0 \%$ relates to 780 observations, corresponding to 183 companies. This therefore shows the low percentage of women on the boards of directors of European listed companies. The CEO and CFO variables show that most of the firms in the sample have male CEOs and CFOs. The mean of the CFO variable is $5.82 \%$, which is slightly higher than the $2.53 \%$ mean of the CEO variable. These figures show that, on average, there are more female CFOs than female CEOs, but nonetheless, the number of female CFOs is not very representative.

As regards the control variables, we can see that the companies in the sample have, on average, a financial leverage of $58.98 \%$, sales growth of $5.11 \%$, an operating cash flow of $10.03 \%$ of total 
assets, ROA of $5.71 \%$ and $\mathrm{MB}$ of 2.52 . The mean of $9.99 \%$ of the LOSS variable indicates that about $10 \%$ of the reported earnings are negative.

\subsection{Analysis of the results}

Table 4 shows the results obtained from regressions (6) and (7). Regarding the gender variable WOMEN, the results suggest that the presence of women on the board of directors does not influence earnings management, since its coefficients are not statistically significant. Thus, in response to Q1, regarding the inverse relationship between earnings management and the presence of women on the board of directors, there is no evidence that a greater presence of women on the board reduces earnings management.

Table 3

\section{Magnitude of earnings management and women on the board}

\begin{tabular}{|c|c|c|}
\hline Variables & EMJones & EMLeuz \\
\hline WOMEN & $\begin{array}{c}0,0001 \\
(0,8778)\end{array}$ & $\begin{array}{c}0,0006 \\
(0,4457)\end{array}$ \\
\hline CEO & $\begin{array}{c}0,0038 \\
(0,4978)\end{array}$ & $\begin{array}{c}-0,0427 \\
(-0,6241)\end{array}$ \\
\hline $\mathrm{CFO}$ & $\begin{array}{c}-\mathbf{0 , 0 0 5 9} * \\
(-1,6619)\end{array}$ & $\begin{array}{c}-0,0190 \\
(-0,4210)\end{array}$ \\
\hline SGROWTH & $\begin{array}{c}0,0303^{* * *} \\
(3,5923)\end{array}$ & $\begin{array}{c}-0,0460 \\
(-0,4871)\end{array}$ \\
\hline SIZE & $\begin{array}{c}-0,0036^{* * *} \\
(-4,0933)\end{array}$ & $\begin{array}{c}-0,0364^{* * *} \\
(-3,9051)\end{array}$ \\
\hline IND & $\begin{array}{c}-0,0069 \\
(-0,5754)\end{array}$ & $\begin{array}{c}0,0616 \\
(0,5656)\end{array}$ \\
\hline OCF & $\begin{array}{c}0,0512 \\
(1,5813)\end{array}$ & $\begin{array}{c}-1,4431^{\text {**** }} \\
(-3,6096)\end{array}$ \\
\hline $\mathrm{MB}$ & $\begin{array}{c}0,0006 \\
(0,6575)\end{array}$ & $\begin{array}{l}-0,0143^{*} \\
(-1,7408)\end{array}$ \\
\hline LOSS & $\begin{array}{c}0,0196^{* * *} \\
(4,2392)\end{array}$ & $\begin{array}{c}0,3375^{* * *} \\
(6,1184)\end{array}$ \\
\hline ROA & $\begin{array}{c}-0,0752^{* *} \\
(-2,2848)\end{array}$ & $\begin{array}{l}-0,7790^{*} \\
(-1,7996)\end{array}$ \\
\hline Constant & $\begin{array}{c}0,0655^{* * *} \\
(4,9422)\end{array}$ & $\begin{array}{c}0,8586^{* * *} \\
(6,8638)\end{array}$ \\
\hline Dummy YEAR & Sim & Sim \\
\hline Dummy SECTOR & Sim & Sim \\
\hline Dummy COUNTRY & Sim & Sim \\
\hline Observations & 2.611 & 2.611 \\
\hline Adjusted $\mathrm{R}^{2}$ & 0,0982 & 0,1763 \\
\hline F test & 4,44 & 9,57 \\
\hline P-value & 0,0000 & 0,0000 \\
\hline
\end{tabular}

Note: ${ }^{* * *},{ }^{* *}$ and ${ }^{*}$ indicate statistical significance at $1 \%$, $5 \%$ and $10 \%$, respectively.
Likewise, we find no evidence that allows us to answer Q2 affirmatively, where we investigate whether the CEO being a woman reduces earnings management practices, due to the statistical irrelevance of the CEO coefficient. Peni \& Vähämaa (2010) and Ye et al. (2010) did not see a significant association either between the CEO's gender and earnings management practices in US and Chinese companies, respectively.

In relation to the results of the CFO variable, we see that it presents a negative coefficient and is statistically significant, at a $10 \%$ level of significance, when measuring earnings management according to the EMJones variable. This result, which relates to $Q 3$, suggests that companies with female CFOs perform less earnings management. This is in line with previous studies, namely that of Barua et al. (2010), which points to the fact that US companies with female CFOs report lower levels of discretionary accruals.

When using the EMLeuz dependent variable, the coefficient of female CFOs, although positive, is not statistically significant, so therefore there is no evidence of an association between the gender of the CFO and the level of income smoothing practiced by the companies.

The results also suggest that larger and more profitable companies practice less earnings management.

Thus, there is evidence that having female a CFO affects the quality of financial reporting favourably as it restricts earnings management practices, thereby supporting the idea that women are more ethical and risk-averse than men. The absence of a statistically significant relationship between the presence of women on the board and earnings management may be due to the low presence of women on the board, which does not allow them to play a more active role in the decisions taken and in supervising financial reports. Shader et al. (1997), among others, argue that when the percentage of women on the board is not significant, their opinions will have no impact on the organization. In our sample, the average percentage of women on the board is only $13 \%$.

Regarding the CEO's lack of influence, which is also documented in previous studies, Ye et al. (2010), Jiang et al. (2010) and Ge et al. 
(2011), among others, argue that the CFO has a greater influence on financial reporting than the $\mathrm{CEO}$ and, as such, has a more decisive role when it comes to earnings management, which may in part explain the results obtained.

\subsection{Additional analysis}

An additional analysis was performed considering the EMJones dependent variable with a sign, in order to analyse the influence of the presence of women on the board of directors, as well as the gender of the CEO and CFO, on the direction of earnings management. The sample was subdivided into two, according to the discretionary accruals sign, and model (6) was estimated for each of the subsamples. Table 5 presents the results.

Table 4

\section{Direction of Earnings Management and Women on the Board}

\begin{tabular}{|c|c|c|}
\hline Variables & EMJones (-) & EMJones (+) \\
\hline \multirow[t]{2}{*}{ WOMEN } & $-0,0001$ & 0,0001 \\
\hline & $(-0,7347)$ & $(0,3488)$ \\
\hline \multirow[t]{2}{*}{$\mathrm{CEO}$} & $-0,0072$ & 0,0019 \\
\hline & $(-1,0363)$ & $(0,1887)$ \\
\hline \multirow[t]{2}{*}{ CFO } & $0,0087^{* *}$ & $-0,0035$ \\
\hline & $(2,4988)$ & $(-0,5680)$ \\
\hline \multirow[t]{2}{*}{ SGROWTH } & $-0,0327^{* * *}$ & $0,0246^{* *}$ \\
\hline & $(-2,6576)$ & $(1,9852)$ \\
\hline \multirow[t]{2}{*}{ SIZE } & $0,0022^{* *}$ & $-0,0034^{* * *}$ \\
\hline & $(2,2710)$ & $(-2.7130)$ \\
\hline \multirow[t]{2}{*}{ LEV } & 0,0054 & $-0,0153$ \\
\hline & $(0,3386)$ & $(-1,1354)$ \\
\hline \multirow[t]{2}{*}{ OCF } & $-0,2608^{* * *}$ & $-0,2472^{* * *}$ \\
\hline & $(-5,6560)$ & $(-5,3208)$ \\
\hline \multirow[t]{2}{*}{ MB } & $-0,0014$ & $-0,0005$ \\
\hline & $(-1,0192)$ & $(-0,5233)$ \\
\hline \multirow[t]{2}{*}{ LOSS } & $-0,0132^{* * *}$ & $0,0283^{* * *}$ \\
\hline & $(-3,0618)$ & $(2,5943)$ \\
\hline \multirow[t]{2}{*}{ ROA } & $0,2692^{* * *}$ & $0,1844^{* * *}$ \\
\hline & $(4,9178)$ & $(3,8562)$ \\
\hline \multirow[t]{2}{*}{ Constant } & $-0,0406^{* *}$ & $0,0814^{* * *}$ \\
\hline & $(-2,4669)$ & $(4,3200)$ \\
\hline Dummy YEAR & Sim & Sim \\
\hline Dummy SECTOR & Sim & Sim \\
\hline Dummy COUNTRY & Sim & Sim \\
\hline Observations & 1.505 & 1.106 \\
\hline Adjusted $\mathrm{R}^{2}$ & 0,2129 & 0,1335 \\
\hline F test & 4,85 & 2,87 \\
\hline P-value & 0,0000 & 0,0000 \\
\hline
\end{tabular}

Note: ${ }^{* * *},{ }^{* *}$ and ${ }^{*}$ indicate statistical significance at the $1 \%, 5 \%$ and $10 \%$ level, respectively.
The first column of Table 4 shows the results for the group with a negative EMJones sign, representing the companies that perform downward earnings management, that is, they use discretionary accruals to reduce their earnings. The second column presents the results for the group with a positive EMJones sign, representing the companies that manage earnings upwards.

As in the main analysis, the CFO variable is the only gender variable that shows a statistically significant coefficient, but only in the group of companies that manage earnings downwards. That is, there is evidence that companies with female CFOs tend to perform downward earnings management, which is in line with previous studies that support the idea that women behave more conservatively and tend to opt for more conservative financial reporting policies than men (Peni \& Vähämaa, 2010; Vähämaa, 2014). No evidence was found that gender influences upward earnings management practices.

The results also suggest that companies with growth prospects, small companies and those posting losses perform less downward earnings management and more upward earnings management. That is, there is a tendency on the part of these companies to use discretionary accruals to increase reported earnings. In turn, companies with lower levels of OCF and more profitable ones tend to perform more downward than upward earnings management.

\subsection{Robustness analysis}

In order to guarantee the robustness of the main analysis results, additional analyses were performed: (i) both regressions, (6) and (7), were estimated using the fixed effects model; (ii) a dummy variable, called CRISIS, was added to the models to control the effects of the 2008-2009 financial crisis, assuming the value " 1 " in the crisis years, and the value " 0 " otherwise; (iii) the WOMEN variable was converted into a dummy, assuming the value " 1 " if there are women on the board of directors and " 0 " otherwise; and (iv) companies from the most representative country, 
the United Kingdom, were excluded from the sample.

The results obtained (not tabulated) are, in general, identical to those reported previously. However, the CFO variable coefficient is no longer significant.

\section{Conclusion}

\section{I Results obtained and contributions to the literature}

This study was conducted to investigate whether the percentage of women on the board of directors and the gender of the CEO and $\mathrm{CFO}$ influence the performance of European listed companies. Given the current debate on the pros and cons of imposing quotas for women in top positions, we tried to understand whether the presence of women in management has a favourable impact on the quality of information reported by companies.

This research contributes to the literature on the determinants of earnings management practices and, in particular, to the still scarce literature on the impact of the presence of women in management on the earnings management and, consequently, financial reporting quality of European listed companies.

Regarding the results, we do not find consistent evidence that greater participation of women on the board of directors or having women in $\mathrm{CEO}$ or CFO positions contributes to reducing earnings management through accruals. We find only a statistically significant negative association between companies with female CFOs and earnings management through the amount of discretionary accruals. The modest share of women on the boards of directors of the sample companies, which is only $13 \%$ on average, and the fact that the CFO has a more direct impact on the financial reporting process than the CEO, may be reasons for these results.

The additional analysis of the influence of women on earnings management suggests that companies with female CFOs tend to perform downward earnings management, which is consistent with the idea that women are more conservative than men in decisions that affect financial reporting. There is also evidence that companies with greater growth prospects, smaller ones and those with losses tend to manage earnings upwards, that is, they use discretionary accruals in order to report better earnings. In turn, companies that generate more operational cash flow and more profitable ones tend to engage more in both downward and upward earnings management.

The results also suggest that larger and more profitable companies perform less earnings management. The main conclusions remain after controlling for the possible effects of the financial crisis, and using different specifications of the sample models and composition.

\subsection{Limitations and future research}

The main difficulty found when preparing this study was the lack of information on the variables associated with gender. Specifically, with regard to the $\mathrm{CEO}$ and $\mathrm{CFO}$ gender variables, there is no direct information in the database, so we had to check the names in each company and complete the missing years by checking the companies' annual reports. In addition, the lack of information on the percentage of women on the board led to a reduction in the size of the sample.

The results of the study should also be interpreted with some caution given the small number of women in chief executive officer and chief financial officer positions in the companies in the sample.

Another limitation is related to the earnings management measures used. Earnings management is difficult to measure as it occurs in different ways (Leuz et al. 2003). We opted for two measures that are widely recognized and used in the earnings management literature, but we are aware that the results obtained may be conditioned by this option.

It would be interesting to extend this study to the universe of non-listed companies given their preponderance in the European business fabric. 


\section{References}

Adams, R. B., Haan, J., Terjesen, S. \& Ees, H. (2015). Board diversity: Moving the field forward. Corporate Governance: An International Review, 23(2), 77-82.

Arun, T., Almahrog, Y. \& Aribi, Z. (2015). Female Directors and Earnings Management: Evidence from UK companies. International Review of Financial Analysis, 39, 137-146.

Barua, A., Davidson, L. \& Rama, D. (2010). $\mathrm{CFO}$ gender and accruals quality. Accounting Horizons, 24(1), 25-39.

Beneish, M. (2001). Earnings management: A perspective. Managerial Finance, 27(12), 3-17.

Bernardi, R. \& Arnold, D. (1997). An Examination of Moral Development within Public Accounting by Gender, Staff Level, and Firm. Contemporary Accounting Research, 14(4), 653-668.

Betz, M., O’Connell, L. \& Shepard, J. (1989). Gender differences in proclivity for unethical behavior. Journal of Business Ethics, 8(5), 321-324.

Birnberg, J. G. (2011). A proposed framework for behavioral accounting research. Behavioral Research in Accounting, 23(1), 1-43.

Bressan, V. G. F., Souza, D. C. D., \& Bressan, A. A. (2017). Income smoothing: a study of the health sector's credit unions. Revista Brasileira de Gestão de Negócios, 19 (66), 627-643.

Bruns, W. \& Merchant, K. (1990). The Dangerous Morality of Managing Earnings. Management Accounting, 72(2), 22-25.

Butz, C. \& Lewis, P. (1996). Correlation of gender-related values of independence and relationship and leadership orientation. Journal of Business Ethics, 15(11), 1141-1149.

Byrnes, J., Miller, D. \& Schafer, W. (1999). Gender differences in risk taking: A meta-analysis. Psychological bulletin, 125(3), 367-383.
Cohn, R. A., Lewellen, W. G., Lease, R. C., \& Schlarbaum, G. G. (1975). Individual investor risk aversion and investment portfolio composition. The Journal of Finance, 30(2), 605-620.

Da Silva, J. O., \& Bezerra, F. A. (2010). Análise do gerenciamento de resultados e o rodízio de firmas de auditoria nas empresas de capital aberto. RBGN: Revista Brasileira de Gestão de Negócios, 12 (36), 304-321.

Dechow, P. \& Schrand, C. (2004). Earnings quality, CFA Institute.

Dechow, P., Sloan, R. \& Sweeney, A. (1995). Detecting Earnings Management. The Accounting Review, 70(2), 193-225.

European Commission (2012). Women in economic decision-making in the EU: Progress report, Publications Office of the European Union.

https://publications.europa.eu/en/publicationdetail/-/publication/8832ea16-e2e6-4095-b1ebcc72a22e28df/language-en

(Accessed 10 January 2018).

Francis, B., Hasan, I., Park, J. C., \& Wu, Q. (2015). Gender differences in financial reporting decision making: Evidence from accounting conservatism. Contemporary Accounting Research, 32(3), 1285-1318.

Gavious, I., Segev, E. \& Yosef, R. (2012). Female directors and earnings management in hightechnology firms. Pacific Accounting Review, 24(1), 4-32.

Ge, W., Matsumoto, D., \& Zhang, J. L. (2011). Do CFOs have style? An empirical investigation of the effect of individual CFOs on accounting practices. Contemporary Accounting Research, 28(4), 1141-1179.

Gilligan, C. (1982). In a different voice: Psychological Theory and Women's Development. Cambridge, MA: Harvard. 
Habib, A. \& Hossain, M. (2013). CEO/CFO characteristics and financial reporting quality: A review. Research in Accounting Regulation, 25(1), 88-100.

Healy, P. \& Wahlen, J. (1999). A Review of the Earnings Management Literature and Its Implications for Standard Setting. Accounting horizons, 13(4), 365-383.

Heminway, J. (2007). Sex, trust, and corporate boards. Hastings Women's Law Journal, 18, 173-193.

Jianakoplos, N. \& Bernasek, A. (1998). Are women more risk averse? Economic inquiry, 36(4), 620-630.

Jiang, J. X., Petroni, K. R., \& Wang, I. Y. (2010). CFOs and CEOs: Who have the most influence on earnings management?. Journal of Financial Economics, 96(3), 513-526.

Linhares, F. S., Costa, F. M. D., \& Beiruth, A. X. (2018). Earnings management and investment efficiency. Revista Brasileira de Gestão de Negócios, 20 (2), 295-310.

Khazanchi, D. (1995). Unethical Behavior in Information Systems : The Gender Factor. Journal of Business Ethics, 14(9), 741-749.

Krishnan, G. \& Parsons, L. (2008). Getting to the bottom line: An exploration of gender and earnings quality. Journal of Business Ethics, 78(12), 65-76.

Lakhal, F., Aguir, A., Lakhal, N., \& Malek, A. (2015). Do women on boards and in top management reduce earnings management? Evidence in France. Journal of Applied Business Research, 31(3), 1107-1118.

Leuz, C., Nanda, D. \& Wysocki, P. (2003). Earnings management and investor protection: An international comparison. Journal of Financial Economics, 69(3), 505-527.
Mason, E.S. \& Mudrack, P.E. (1996). Gender and ethical orientation: A test of gender and occupational socialization theories. Journal of Business Ethics, 15(6), 599-604.

Merchant, K. a. \& Rockness, J. (1994). The ethics of managing earnings: An empirical investigation. Journal of Accounting and Public Policy, 13(1), 79-94.

Park, Y.W. \& Shin, H. H. (2004). Board composition and earnings management in Canada. Journal of corporate Finance, 10(3), 431-457.

Peasnell, K. V, Pope, P.F. \& Young, S. (2005). Board monitoring and Earnings Management: Do Outside Directors Influence Abnormal Accruals? Journal of Business Finance \& Accounting, 32(7-8), 1311-1346.

Peni, E. \& Vähämaa, S. (2010). Female executives and earnings management. Managerial Finance, 36(7), 629-645.

Riley, W.B. \& Chow, K.V. (1992). Asset allocation and individual risk aversion. Financial Analysts Journal, 48(6), 32-37.

Schipper, K. (1989). Commentary on earnings management. Accounting Horizons, 3(4), 91-102.

Shrader, C. B., Blackburn, V. B., \& Iles, P. (1997). Women in management and firm financial performance: An exploratory study. Journal of Managerial Issues, 9 (3), 355-372.

Srinidhi, B., Gul, F. a. \& Tsui, J. (2011). Female directors and earnings quality. Contemporary Accounting Research, 28(5), 1610-1644.

Subramanyam, K.R., (1996). The pricing of discretionary accruals. Journal of accounting and economics, 22(1), 249-281.

Terjesen, S., Sealy, R. \& Singh, V. (2009) Women directors on corporate boards: A review and research agenda. Corporate Governance: An International Review, 17(3), 320-337. 
Terjesen, S., Aguilera, R. \& Lorenz, R. (2015) Legislating a woman's seat on the board: Institutional factors driving gender quotas for boards of directors. Journal of Business Ethics, 128 (2), 233-251.

Vähämaa, E. (2014) Executive Turnover and Earnings Management. Accounting Perspectives, 13, 2, 103-122.
Xie, B., Davidson, W. \& Dadalt, P. (2003). Earnings management and corporate governance: The role of the board and the audit committee. Journal of Corporate Finance, 9(3), 295-316.

Ye, K., Zhang, R. \& Rezaee, Z. (2010). Does top executive gender diversity affect earnings quality? A large sample analysis of Chinese listed firms. Advances in Accounting, 26(1), 47-54. 


\section{APPENDIX \\ Description of study variables}

\begin{tabular}{|c|c|c|}
\hline Variable & Definition / Calculation & Supporting Literature \\
\hline \multicolumn{3}{|c|}{ Dependent variables } \\
\hline EMJones & $\begin{array}{l}\text { Discretionary accruals calculated according to the modified Jones } \\
\text { model }\end{array}$ & Dechow et al. (1995) \\
\hline EMLeuz & $\mid$ Accruals $|/|$ OCF $\mid$, where OCF is the operating cash flow & Leuz et al. (2003) \\
\hline \multicolumn{3}{|c|}{ Independent variables associated with gender } \\
\hline WOMEN & $\%$ of women on the board of directors & Arun et al. (2015) \\
\hline $\mathrm{CEO}$ & $\begin{array}{l}\text { Dummy variable that assumes the value " } 1 \text { " if the chief executive } \\
\text { officer of the company is female and the value } 0 \text { otherwise }\end{array}$ & Peni \& Vähämaa (2010); Ye et al. (2010) \\
\hline $\mathrm{CFO}$ & $\begin{array}{l}\text { Dummy variable that assumes the value "1" if the company's } \\
\text { chief financial officer is female and the value } 0 \text { otherwise }\end{array}$ & $\begin{array}{l}\text { Arun et al. (2015); Barua et al. (2010); Peni \& } \\
\text { Vähämaa (2010); Ye et al. (2010) }\end{array}$ \\
\hline \multicolumn{3}{|c|}{ Independent Control Variables } \\
\hline SGROWTH & Sales Growth: Annual Variation in Sales / Previous Year Sales & $\begin{array}{l}\text { Arun et al.( 2015); Barua et al. (2010); Peni \& } \\
\text { Vähämaa (2010); }\end{array}$ \\
\hline SIZE & Size: Logarithm of Total Assets & $\begin{array}{l}\text { Arun et al. (2015); Barua et al. (2010); Park } \\
\text { \& Shin (2004); Peni \& Vähämaa (2010); Ye et } \\
\text { al. (2010) }\end{array}$ \\
\hline IND & Indebtedness: Total Liabilities / Total Assets & $\begin{array}{l}\text { Arun et al. (2015); Barua et al. (2010); Park \& } \\
\text { Shin (2004); Peni \& Vähämaa (2010) }\end{array}$ \\
\hline OCF & Operating Cash Flow / Total Assets & Arun et al. (2015); Barua et al. (2010) \\
\hline $\mathrm{MB}$ & Market-to-Book ratio: Market Value / Equity & $\begin{array}{l}\text { Arun et al. (2015); Barua et al. (2010); Peni \& } \\
\text { Vähämaa (2010); }\end{array}$ \\
\hline LOSS & $\begin{array}{l}\text { Losses: dummy variable that assumes the value " } 1 \text { " if net } \\
\text { earnings are negative in year } t \text {, and value " } 0 \text { " otherwise }\end{array}$ & $\begin{array}{l}\text { Arun et al. (2015); (Peni \& Vähämaa (2010); } \\
\text { (Ye et al. 2010) }\end{array}$ \\
\hline ROA & $\begin{array}{l}\text { Return on Assets: Earnings Before Extraordinary Items / Average } \\
\text { Total Assets of the Year }\end{array}$ & Barua et al. (2010) \\
\hline YEAR & $\begin{array}{l}\text { Represents the set of dummy variables for each year and assumes } \\
\text { the value " } 1 \text { " for data for that year and " } 0 \text { " otherwise }\end{array}$ & Arun et al. (2015); Peni \& Vähämaa (2010) \\
\hline COUNTRY & $\begin{array}{l}\text { Represents the set of dummy variables for each country and } \\
\text { assumes the value " } 1 \text { " if the company belongs to that country } \\
\text { and " } 0 \text { " otherwise }\end{array}$ & \\
\hline SECTOR & $\begin{array}{l}\text { Represents the set of dummy variables for each sector and } \\
\text { assumes the value " } 1 \text { " if the company belongs to that sector and } \\
\text { "0" otherwise }\end{array}$ & Arun et al. (2015); Peni \& Vähämaa (2010) \\
\hline
\end{tabular}




\section{Supporting Agencies:}

FCT - Fundação para a Ciência e Tecnologia (Portugal), national funding through research grant (UID/ SOC/04521/2013).

\section{About the Authors:}

1. Tiago Gonçalves, PhD in Management, Universidade de Lisboa - ISEG, Lisbon, Portugal, E-mail: tiago@iseg.ulisboa.pt

\section{ORCID}

\section{(iD 0000-0002-1031-0032}

2. Cristina Gaio, $\mathrm{PhD}$ in Accounting, ISCTE, Lisbon, Portugal, E-mail: cgaio@iseg.ulisboa.pt

\section{ORCIID}

\section{(iD)0000-0002-4906-1547}

3. Tatiana Santos, MSc in Accounting, Finance and Taxation, ISEG, Lisbon, Portugal, E-mail: tatiana_ santos_21@hotmail.com

\section{ORCIID}

D0000-0001-5356-5302

Has any preliminary version of this article been presented / published in annals of scientific congresses or is it derived from a thesis or dissertation?

Impacto da presença de mulheres na administração na gestão de resultados, Master’s thesis, ISEG, 2015

\section{Contribution of each author}

Each author should take responsibility for at least one component of the paper. If the article is approved for publication, the authors should indicate in the diagram below, what was the contribution of each.

\begin{tabular}{lccc}
\hline Contribution & [Author 1] & [Author 2] & [Author 3] \\
\hline 1. Definition of research problem & $\sqrt{ }$ & $\sqrt{ }$ & $\sqrt{ }$ \\
2. Development of hypotheses or research questions (empirical studies) & $\sqrt{ }$ & $\sqrt{ }$ & $\sqrt{ }$ \\
3. Development of theoretical propositions (theoretical work) & $\sqrt{ }$ & $\sqrt{ }$ \\
4. Theoretical foundation / Literature review & $\sqrt{ }$ & $\sqrt{ }$ & $\sqrt{ }$ \\
5. Definition of methodological procedures & $\sqrt{ }$ & $\sqrt{ }$ \\
6. Data collection & $\sqrt{ }$ & $\sqrt{ }$ \\
7. Statistical analysis & $\sqrt{ }$ & $\sqrt{ }$ \\
8. Analysis and interpretation of data & $\sqrt{ }$ & $\sqrt{ }$ \\
9. Critical revision of the manuscript & & $\sqrt{ }$ \\
10. Manuscript writing & & $\sqrt{ }$ \\
11. Other (please specify which) & & $\sqrt{ }$
\end{tabular}

This information will be available in publications as end notals in accordance with the criteria, policies and procedures for admission and permanence of scientific journals in SciELO Brazil Collection. 